\title{
Nubian ibex in the Eastern Desert, Egypt
}

Paul R. Krausman and William W. Shaw

In 1984, when the authors were working in the central part of Egypt's Eastern Desert, they found some large tracks and followed them. From the top of a sand dune, they had a brief but clear view of an adult male Nubian ibex. This unexpected sighting confirms that there is at least one population in this part of the Eastern Desert; the last report of ibex in the area was in 1927.

The ibex Capra ibex has a wide range in southem Europe and Asia (Ellerman and Morrison-Scott, 1951), but its range in Africa is limited (Corbet, 1978). The Nubian ibex (C. $i$. nubiana) is restricted to the Sinai Peninsula and the Eastern Desert in Egypt (Osborn and Helmy, 1980). The recent status of the Nubian ibex is documented in the Sinai Peninsula (Baharav and Meiboom, 1981) but its distribution and status in the Eastern Desert is not clearly known. Historically, and as recently as the 20th century, ibex were reported from the bluffs overlooking the Nile River eastward to all the plateaux and peaks of the Eastern Desert and Sinai Peninsula (Osborn and Helmy, 1980). Prior to the completion of the railway between Luxor and Aswan in the early 1900 s, ibex came to the Nile for water (Fowler, 1932). In this century, however, the range of the ibex has been reduced and the population has declined to dangerously low levels. Nubian ibex have been captured and killed for pleasure, profit, meat and domestication (Russell, 1949, 1951).

Most reports of ibex in Egypt's Eastern Desert were made prior to 1900 (Osborn and Helmy, 1980). The establishment of an ibex sanctuary in Wadi Rishrash in the northern part of the Eastern Desert by Prince Kemal el Din between 1900 and 1940 probably saved the ibex from annihilation 176 in this area (Halton, 1935). Some ibex have been observed there as late as 1960 (Talbot, 1960). Although it is suspected that relict populations exist in remote mountain peaks of other areas of the Eastern Desert, actual observations after 1932 are lacking.

On 8 February 1984, while evaluating a portion of the Eastern Desert, we were in the Assiut University Protected Area (AUPA), which is located $45 \mathrm{~km}$ east of Assiut, Egypt, (Figure 1). AUPA includes Wadi Habib $\left(27^{\circ} 11^{\prime} \mathrm{N}, 31^{\circ} 46^{\prime} \mathrm{E}\right)$ and its junction with Wadi el Assuit $\left(27^{\circ} 10^{\prime} \mathrm{N}, 31^{\circ}\right.$ $16^{\prime} \mathrm{E}$ ). We travelled by jeep approximately $25 \mathrm{~km}$ from the junction of Wadi el Assiut and Wadi Habib to an area where the sandstone hills were partially covered with sand, forming a narrow channel in the wadi. While walking along the cliff edges, we noted large tracks in the sand at the base of a heavily browsed Acacia spp. We followed the tracks across a small dry lake bed and up the side of a 17-25 $\mathrm{m}$ sand dune. On the rugged peaks across from the sand dune $(<100$ m) we spotted an adult male Nubian ibex. He was clearly in view for some 5 seconds before turning and running out of sight.

It was believed that ibex had been eliminated from this part of the Eastem Desert (Schomber, 1963). The last report of ibex in Wadi el Assuti and Wadi Habib was in 1927 when one was observed and shot (Osborn and Helmy, 1980).

Our observation confirms that at least one relict population exists in the central portion of the Eastern Desert. With adequate protection and management, small viable populations may be maintained. Sources of free-standing water have

Oryx Vol 20 No 3. July 1986 


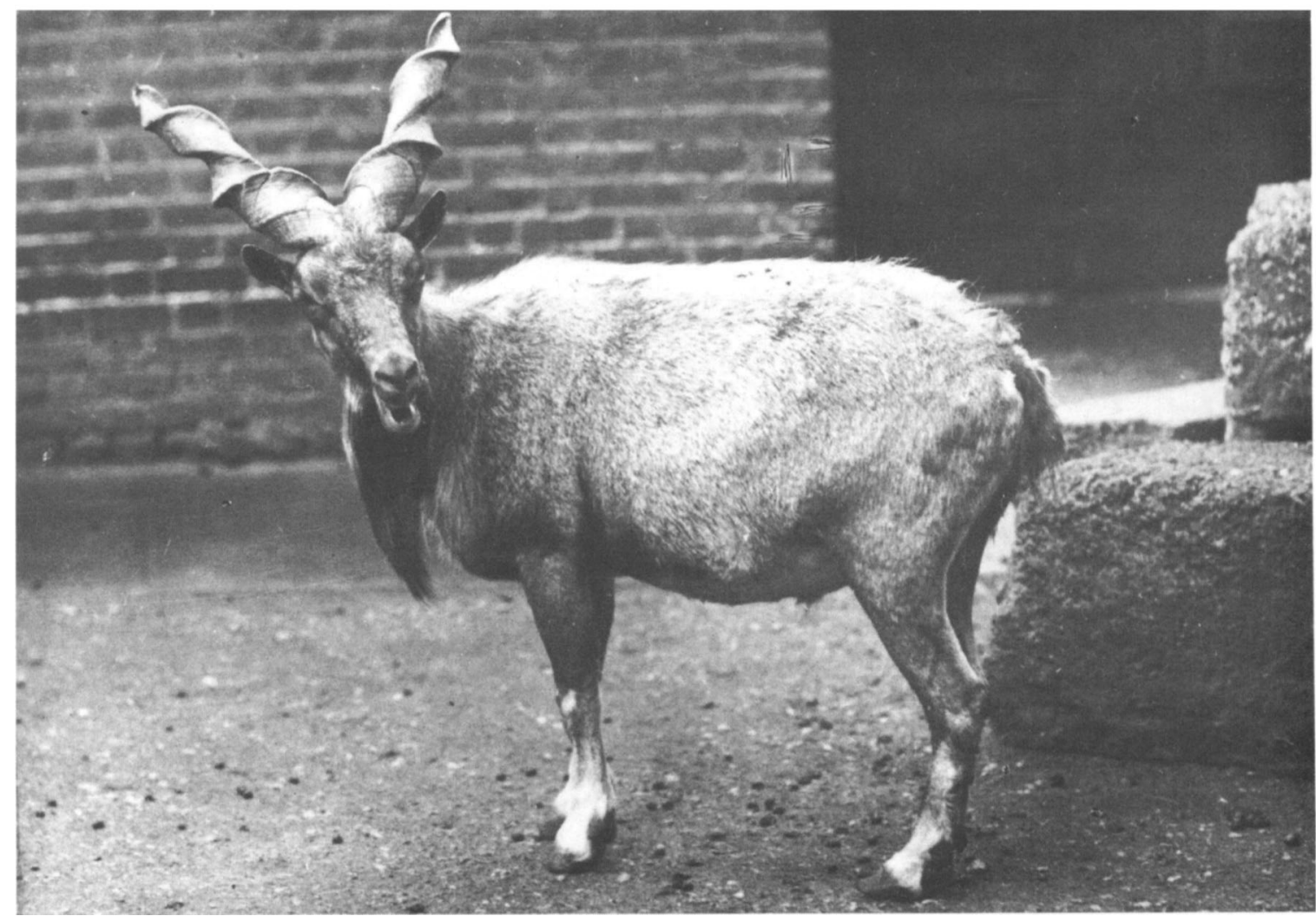

Nubian ibex (Zoological Society of London).

not been located in AUPA. The proper development of water sources may improve the habitat for ibex and other wildlife species.

\section{Acknowledgment}

We appreciate the help of Dr A. Maher Ali, Assiut University, in introducing us to AUPA. Support was from the mini-linkage programme, USAID, Cairo, Egypt, Assiut University, Assiut, Egypt, and the University of Arizona, Tucson.

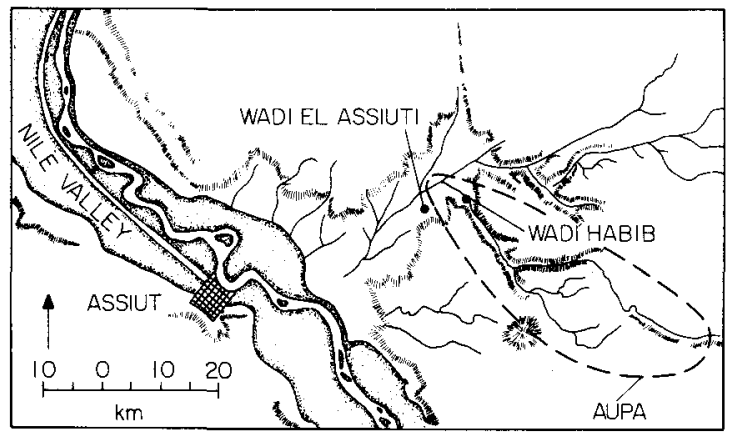

Figure 1. Location of Assiut University Protected Area (AUPA), Wadi El Assiuti and Wadi Habib in the Eastern Desert, Egypt.

Nubian ibex in Eastern Desert. Egypt

\section{References}

Baharav, D. and Meiboom, U. 1981. The status of the Nubian ibex Capra ibex nubiana in the Sinai Desert. Biol. Conser. 20,91-97.

Corbet, G.B. 1978. The Mammals of the Palaearctic Region A Taxonomic Review. Cornell University Press, Ithaca. NY.

Ellerman, J.R. and Morrison-Scott, T.C.S. 1951. Checklist of Palearctic and Indian Mammals. British Museum of Natural History, London.

Fowler, S.S. 1932. Notes on the recent mammals of Egypt, with a list of the species recorded from the kingdom. Proc. Zool. Soc., London, 32, 368-450.

Halton, L. 1935. An Egyptian game reserve. Field, 166, 1520.

Osborn, D.J. and Helmy I. 1980. The contemporary land mammals of Egypt (including Sinai). Fieldiana, 5, 79.

Russell. T. 1949. Desert fauna. Bull. Zool. Soc. Egypt, 8, 5-8.

Russell, T. 1951. The fauna of the Egyptian deserts. Bull. Zool. Soc. Egypt, 9, 1921

Schomber, H.W. 1963. Wild life in the Sudan. IV. Afr. Wild Life. 17, 117-124

Talbot, L. 1960. A look at threatened species. Oryx, V, 153-293.

Paul R. Krausman and William W. Shaw, Wildife, Fisheries, and Recreation Resources Division, School of Renewable Natural Resources, University of Arizona, Tucson, AZ 85721. USA. 